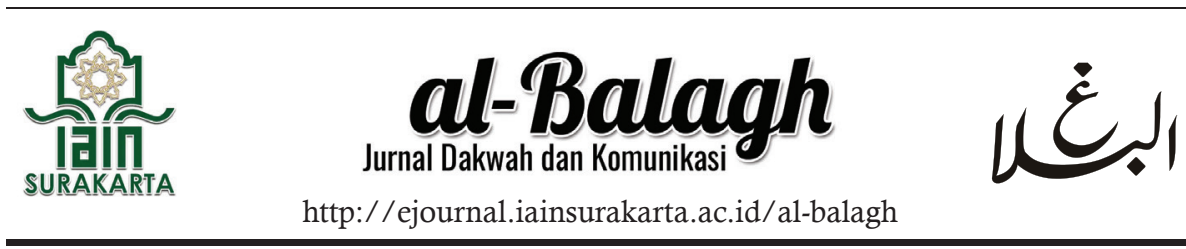

\title{
AHOK AND BLASPHEMY CASE IN KOMPAS AND REPUBLIKA ONLINE MEDIA: A CLASH OF IDEOLOGIES
}

\author{
Muhammad Beni Saputra
}

Universitas Islam Negeri Sulthan Thaha Saifuddin Jambi

\begin{tabular}{|c|c|}
\hline & Abstract \\
\hline Keywords: & Ahok's speech in Kepulauan Seribu was viral on the internet. The \\
\hline $\begin{array}{l}\text { Ahok; blasphemy; } \\
\text { Kompas and } \\
\text { Republika; media } \\
\text { framing }\end{array}$ & $\begin{array}{l}\text { speech put the ethnic Chinese Christian Jakarta governor into a } \\
\text { national spotlight. Mass media then sought to interpret Ahok's } \\
\text { speech by framing its content. Using Robert Entman's framing } \\
\text { theory, this paper analyzes online media framing of Republika }\end{array}$ \\
\hline & $\begin{array}{l}\text { and Kompas on Ahok and a blasphemy case involving him. } \\
\text { Content analysis of the news articles published by the two online } \\
\text { media shows that the framing of Ahok and the blasphemy } \\
\text { case differ in reporting and focus. Kompas Online mostly } \\
\text { reported positive news about Ahok, while Republika Online } \\
\text { demonstrated a different pattern of framing. On the blasphemy } \\
\text { case, Kompas Online focused on defense, whereas Republika } \\
\text { Online emphasized that Ahok had insulted Islam and had to } \\
\text { be jailed. These differences are manifestations of an ideological } \\
\text { clash between Kompas and Republika. }\end{array}$ \\
\hline
\end{tabular}

Correspondence:

e-mail: m.benisaputra@uinjambi.ac.id 


\begin{tabular}{l}
\hline \\
\hline Kata kunci: \\
Ahok; Kompas \\
dan Republika; \\
pembingkaian \\
media; penistaan \\
agama \\
\hline
\end{tabular}

\begin{abstract}
Abstrak
Pidato Ahok di Kepulauan Seribu viral di internet. Pidato ini menjadikannya sebagai Gubernur Jakarta Nasrani keturunan Tionghoa menjadi sorotan nasional. Keberadaan media massa selanjutnya berupaya untuk menginterpretasikan pidato Ahok dengan membingkai apa yang menjadi konten pidatonya. Menggunakan teori pembingkaian Robert Entman, tulisan ini menganalisis pembingkaian media online Kompas dan Republika terhadap Ahok dan kasus penistaan agama. Analisis isi dari artikel berita yang diterbitkan oleh dua media online tersebut menunjukkan bahwa pembingkaian mengenai Ahok dan kasus penistaan agama berbeda dalam hal pelaporan dan fokus berita. Pelaporan Kompas online didominasi berita positif mengenai Ahok, sementara Republika online menunjukkan bingkai yang berbeda. Mengenai kasus penistaan agama ini, Kompas online fokus pada pembelaan, sedangkan Republika online memberikan penekanan bahwa Ahok telah menista agama Islam dan harus dipenjara. Perbedaan-perbedaan ini menjadi manifestasi pertabrakan ideologi antara Kompas dan Republika.
\end{abstract}

\title{
How to cite (APA 7th Edition):
}

Saputra, M. B. (2020). Ahok and Blasphemy Case in Kompas and Republika Online Media: A Clash of Ideologies. Al-Balagh: Jurnal Dakwah dan Komunikasi, 5(1). 59-94 https://doi.org/10.22515/al-balagh.v5i1.1991

\section{INTRODUCTION}

"It is possible that deep in your heart, you don't vote for me because of being deceived by using all those kinds of $\mathrm{Al}$ Maidah 51"(BBC, 2016).

These above words, which were taken from a speech video recorded in the Kepulauan Seribu on 27 September 2016, spread as a nationwide controversy after a man named Buni Yani uploaded it to the internet. As the eyes and ears of the people, mass media tried their best to interpret the event and built suitable frames on the statement. Some deemed it a 
blasphemy of religion and therefore Ahok had to be put on trial, while others argued that the news defended Ahok whom they considered a victim of a political chaos of the approaching 2017 Jakarta Gubernatorial Election. Two of the media competing to build dominant frames on Ahok's words were Republika and Kompas.

The active reaction of Kompas and Republika on Ahok's speech is understandable considering these two media were given birth and raised by two contrasting ideological streams: Islam and Christianity. Republika was founded by the Indonesian Association of Muslim Intellectuals (ICMI) (Hefner, 1993; Hefner, 1997) in the early 1990s as an effort to provide an Islamic perspective in Indonesian journalism. This goal has influenced Republika's reporting since its establishment until the present day. By contrast, Kompas was initially an Indonesian Catholic Party-affiliated media (Wijayanto, 2017) founded in the early 1960s by a number of Catholic journalists from the Intisari weekly magazine. Some prominent Catholic figures such as P.K. Ojong, Jakob Oetama, R.G. Doeriat, Frans Xaverius Seda, Policarpus Swantoro, R. Soekarsono, as well as elements of the Supreme Council of Bishops Indonesia (MAWI), including the Catholic Party, The Union of Catholic University Students of the Republic of Indonesia (PMKRI), and Catholic Youths and Women got involved in the creation of Kompas. The affiliation earned Kompas a nickname of 'Komando Pastur' or the Pastor Command.

Despite having identical historical origins, today's Republika and Kompas are different. Republika still displays its original face as an Islamaffiliated media as seen in its news coverage as well as on its website's navigation tabs which bear some Islamic features. Republika even openly admits its status as an Islamic media (Raharjo, 2017). In contrast, Kompas opts to go more secular and claims to be free of any ideological and political interests, a moderate strategy that has been proven effective in 
the Indonesian Moslem majority market. As a result, Kompas progresses significantly and becomes Indonesia's largest media without losing its ideological interests: defending Christianity on issues regarding the religion and its believers (Yani, 2002; Aprianti, 2014). At the same time, Kompas remains unrestricted to play his role as 'the ruling class' (Marx \& Engels, 1972) which has a means of message production to stem the increasing hegemony of Islamic political ideology.

Ideology is inseparable from media because, as Althusser theorized, the media are one of the 'ideological state apparatuses' whose task is to disseminate the ideology of certain groups (Althusser, 2006). Stuart Hall defines ideology in communication studies as 'organized belief system or set of values' that refers to national culture, class position, and views of media owners disseminated through communication (McQuail, 2010). Hall argues that the media are involved in the politics of significations by producing images of the world and giving certain meanings to them which not only reflectreality but also represent it (Croteau \& Hoynes, 2013).

Talk about how the media represents reality, media basically have a role to transmit the message of communication widely to the public. In this case-the mass-media especially is capable to distribute some information and allows the public to access it widely (Tamburaka, 2013). At least, there are three characteristics of the most dominant mass media, such as 1) business oriented; 2) based on the development of media technology; and 3) a reflection of people's lives (Anggraeni, 2018). Thus, mass media are the media context that cannot be separated from the realm of business. Through the basis of technology used, the mass media is able to disseminate information for the public, so that the information conveyed basically cannot only consumed privately, but it can be widely accessed by everyone who uses mass media. In addition, the mass media in its condition is also able to represent how humans live based on the reality they constructed (Wahid \& Pratiwi, 2018). 
The media frame is considered important for media to limit the preparation and packaging of news. This is a part of media efforts to build a number of facts that can be raised in accordance with media ideology and the needs of the audience (Wibiyanto \& Hastiningsih, 2019). In this context, some research talks about framing of media and politics, for instance, (Entman, 2007); (Hänggli \& Kriesi, 2010); (Borah, 2011); (Matthes, 2012); (Azpíroz, 2014); (Gronemeyer \& Porath, 2017); and (Brugman \& Burgers, 2018). Besides, the existence of framing concept and media setting' agendas as a basis for this research can also be found in some references by (Scheufele, 1999); (Scheufele, 2004); (Scheufele \& Tewksbury, 2007); and (Alonso, 2014).

How the media develop aspects of managing issues, this departs from the way an issue is raised, constructed, then managed and brought in a certain perspective based on the perspective of the media. In this position, the media certainly must be neutral. Moreover, in this position, the media certainly must be neutral, if it is associated with an issue that tends to be sensitive and contains the competing interests of several parties. Betting issues include the presence of positive and negative tones in the media frame, so that when examined further, issue management is part of the workings of the mass media. While the mass media itself, ultimately has a large role in constructing public opinion on the emergence and possibility of numerous people's perspectives on the issues raised (Wibiyanto \& Hastiningsih, 2019).

Ideology of media plays a central role in the normalization process of an event that includes and excludes certain ideas and actions and determines contents of a message (Croteau \& Hoynes, 2013). Such a technique aims to influence a wider community, therefore it adopts a particular media's worldview, planting an understanding that the media perspective represents the experience of the whole human being (Croteau \& Hoynes, 2013). 
Through the explanation, the media in their position must be able to provide continuity of information which surely is "good" for the community. This is due to the wide influence generated by the media, how the media analyze the political context in a neutral way, this is a big challenge for the concept of political democracy (Aelst et al., 2017) which is conducted. The assumption is that the position of biased media (Wolton, 2019), will certainly be a special influence on the democratic life of a country, especially in the political problems of it.

The ideological difference between Republika and Kompas pushed both media to offer perspectives aiming at protecting political aspirations of Christians and Muslims. It became more apparent, especially after the Bela Islam (defending Islam) 411 and 212 movements, a series of Muslim protests against Ahok's controversial statement. While on the surface the protestors demanded Ahok's imprisonment, at the level of ideology 411 and 212, and the reaction to them from the Christian group were an affirmation of paranoia feelings against the Islamization or Christianization of Indonesia (Hoon, 2016).

The feeling of being threatened between Indonesian Muslims and Christians (Mujiburrahman, 2006) was increasingly evident in the second round of the 2017 Jakarta Gubernatorial election, which put Ahok in a direct competition against the Islamist party backed (PKS) Anies Baswedan. Whereas scholars branded the 2017 election as a battle between liberal Muslims versus fundamentalists, or between rational versus racist voters (Lim, 2017), yet the true reality did not entirely tell so. In fact, it was a clash of ideologies between Christian and Islamic groups as seen in the full support from Indonesian Christians and ethnic Chinese for Ahok (RMOL, 2017), the notable participation of traditionally politically apathetic Chinese voters (Purwadi, 2017), and Ahok's landslide victory in several Christian majority polling stations (Ilham, 2017c). Moreover, Muslim groups in the Indonesian capital, though slightly split, mostly 64 
voted for Anies which helped him seized victory (Khadafi, 2017). Such a complex dynamic influenced Republika and Kompas news framing of Ahok and his blasphemy case. For Republika, Ahok was a threat to the Muslim hegemony of Jakarta's politics thus he had to be framed as 'other'. Similarly, Kompas expected Ahok to become the 'shepherd of salvation' for Jakarta's residents through taking advantage of his dual minority status.

A large body of scholarship has been devoted to media reporting on Ahok's blasphemy focusing on the reality created by the case (Nautico, 2018) inconsistent reporting treatment on Ahok's trial (Sidik, 2017) different framing of Ahok's case (Sobari \& Ramdani, 2019; Nurhaliza \& Tanto, 2019; Suganda et al., 2018; Mayasari, 2017; and Indra K. \& Suprihartini, 2017). While all these scholarly works give a significant contribution to the understanding of media reporting on Ahok's case, yet a key issue has gone unobserved. Prior studies paid too much attention to media framing with little emphasis on how frames built by news media are ideologically motivated. Furthermore, previous studies did not notice the interconnection between the decreasing nature of the Indonesian press freedom and the ideologically-motivated framing for and against Ahok made by religiously-affiliated news media such as Kompas and Republika. By analysing all news articles published by Kompas and Republika from the emergence of Ahok's case to the judge's verdict using Robert Entman's framing theory, this paper offers a new insight on not only the development of the case but also its contextual force. More specifically, this paper argues that the framing difference between Kompas and Republika is not a mere coincidence but a consequence of the ideological streams attached to the two Indonesia's prominent news outlets.

Besides, discussing Kompas and Republika's framing of Ahok and his blasphemy case, and how ideology plays a role in the news making process cannot be more imperative in the midst of the multi-layered problems being faced by the Indonesian media. Media convergence (Tapsell, 2015), 
self-censorship among journalists (Tapsell, 2012a), owners' intervention of the independence and autonomy in the editorial room (Tapsell, 2012b), and the dominance of oligarchs in the Indonesian media (Winters, 2013) have all seriously eroded the country's media trustworthiness.

\section{METHODS}

This qualitative research uses data from Kompas.com and Republika.co.id. It's supposed to be from 27 September 2016 to 15 May 2017 Kompas.com and Republika.co.id were selected because both media have historical affiliations with Islam and Christianity. The online versions of these two media were chosen due to the intensity of reporting and ease of access. Besides, by 2017 the number of Indonesians reading online news had surpassed that of print (Reily, 2017). The reason behind the data collection from 27 September 2016 to 15 May 2017 is that September $27^{\text {th }}$ was the day Ahok paid a visit to Kepulauan Seribu and delivered the provocative speech. This date is important to see how the reaction of Kompas and Republika Online to the phenomenon and how the initial framing the two media made. Meanwhile, May $15^{\text {th }}$ is aimed to see how both media behaved against the court's decision on Ahok and how they reacted to Ahok's verdict. The period from 27 September 2016 to 15 May 2016 was a time to influence public opinion and built dominant frames in hope of being accepted by audience as a common sense.

Kompas and Republika Online have sufficient resources to make their frames of Ahok and his blasphemy case resonate and dominate the public sphere. Most of Kompas readers are highly educated, economically privileged, and politically influential (Wijayanto, 2019). Kompas Gramedia, the parent company of Kompas, is the biggest and the most prestigious media conglomerate in Indonesia which owns 43 magazines and tabloids, 11 local newspapers, 5 book publishers (Lim \& Arizona, 2011). In 2019, Kompas online was the ninth most popular website in Indonesia and its 66 
subsidiary online news media, while Tribunnews.com was the second (Alexa, 2019).

Despite not being as large as Kompas in terms of prestige and size, Republika is undeniably Indonesia's most prominent Islamic news media whose main readers are young middle-class Muslims. In 2016, Republika claimed to rank number 3 as the most read newspaper in Indonesia (Steele, 2018). Similar to Kompas, Republika's parent company, Mahaka Media, also owns several radio stations, a TV channel (Jak TV), and a publisher (Media, 2019). All these different message production means allowing Kompas and Republika to massively circulate their Ahok's frames, giving readers an understanding of who is Ahok and what is actually happening regarding his case. Furthermore, their privileged readers have social capital to influence others regarding Ahok's case through their extensive networks in government offices, media companies, and universities.

Data collection was done by downloading news articles with keywords 'Ahok' and 'Ahok Blasphemy Al-Maidah' from the Google search engine using the advanced search feature. There were in total 1496 (488 Kompas.com and 1008 Republika.co.id) news articles within an approximately eight-month period from 27 September 2016 to 15 May 2016 with the 'Ahok' keyword. The 'Ahok Blasphemy Al-Maidah' keyword generated 210 articles, of which Kompas covered 65 articles and Republika 210 articles. All these articles were exported to the latest qualitative computer software NVivo 12 (Edhlund \& McDougall, 2019; Jackson \& Bazeley, 2019), and for a content analysis procedure using Entman's framing theory as a coding guide.

According to Entman, framing is "to select some aspects of a perceived reality and make them more salient in a communicating text" to promote a specific "problem definition, causal interpretation, moral evaluation, and/or treatment recommendation" (Entman, 1993). Entman argues that an article may or may not cover all the four features and a Ahok and Blasphemy Case in Kompas and Republika Online Media: A Clash of Ideologies 
frame does not necessarily have to contain all of them (Entman, 1993). Two aspects are usually featured in framing: texts and images (Castells, 2013). Framing through texts is generally conducted by associating texts with symbols that are easy to recognize or by substituting or repeating particular words (Entman, 1993). In contrast, framing through images relies on pictures that are highly salient in a culture or images that are 'noticeable, understandable, memorable, and emotionally charged'.

More culturally recognizable images and words have a high potential to evoke similar thoughts and feelings in people (Entman, 2004). This will allow an 'image-making' process in people's minds to start which in turn affects people's judgment and inference making (Pan \& Kosicki, 1993). Framing works 'by activating the mind with a proper stimulus' (Castells, 2013) instructing people's minds to consider 'what exists, what happens, and what matters' (Gitlin, 2003), and become a phenomenon in seeing how public opinion is raised (Chong et al., 2007). In many settings, the effect of framing raises doubts on the welfare conclusions drawn from revealed preference analysis (Goldin \& Reck, 2019).

Although analyzing a massive amount of news to identify Kompas and Republika Online framing of Ahok and his blasphemy case, this research does not provide a complete picture of a clash of ideologies between Kompas and Republika Online in particular with regards to the research topics. It is due to the absence of direct newsroom observations as well as interviews with the owners of the two media to assess and clarify the data.

\section{RESULTS AND DISCUSSION A Clash of Ideologies}

The buzzing stories behind Ahok's case with massive protests by Muslims against the Christian-Chinese Jakarta governor, the nearing 2017 Jakarta Gubernatorial Election, the tendency of voters to vote in 
accordance with their religious and ethnic status (Riana, 2016), and the different ideologies (Islam and Christian) that are deeply integrated in Kompas and Republika provide a justification for both media as to why they had to frame Ahok in strikingly different ways. Kompas's source of ideology is Jacob Oetama as he is one of the founders, the president commissioner, and the 'father' of Kompas who has the most share in the media company (Keller, 2009). Jakob Oetama is a conservative, capitalist Christian who embraces the principle of transcendental humanism. While in philosophy, the term means that humans have inherent rights to get proper treatment outside nature (Ferry, 2002), and for Jakob, it is translated into faith-based humanism with God being a central hub (Kompas, 2016).

Jakob has been through long, intensive processes to build a strong foundation of his Christian ideology through a number of ways. He first went to a Christian school called the Yogyakarta Seminary High School in 1951 to fulfil his dream to become a priest. Yet as the time went by, Jakob changed his life goal from being a priest to a teacher under the supervision of a pious Christian, Yohanes Yosep Supatmo. Jakob then taught at a Christian school owned and operated by a group of catholic priests called the congregation of Ordo Fratrum Minorum (OFM). During his spell as a teacher, Jakob resided in a catholic school complex, Vincentius, which was located in Kramat Raya, Central Jakarta (Kompas, 2016). However, Jakob once again changed his profession. Living life as a teacher seemed to be unsatisfactory for him, thus he decided to turn himself into a journalist. Jakob had actually been recommended by his history teacher, Van den Berg SJ, a Dutch priest, to study at Columbia University on a scholarship. But a serious conversation between him and priest JW Oudejans OFM reinforced his commitment to work in the media (Galih, 2016). He believed, as suggested by the priest, that becoming a journalist was the noblest profession for him. Throughout his life, Jakob had worked for several Christian media such as Penabur Weekly and Intisari Weekly before co-founding Kompas with Petrus Kanisius Ojong. 
In contrast, the Islam ideology in Republika has been well imbedded since the media's establishment by the Indonesian Association of Muslim Intellectuals (ICMI) in 1993. The establishment of Republika indeed was aimed to channel the political voice of Islam after having been side-lined, and sometimes repressed, by Suharto until the 1980s. The authoritarian president had a special relationship with Christian-affiliated top figures and organizations that caused serious troubles to Muslims. In addition, Republika is committed to serving Indonesia's Muslims earning its a reputation of a conservative Islamic paper that follows MUI, NU, and Muhammadiyah (Steele, 2018). Until the 2000s Republika had been sponsored by influential Muslim business elites who helped the media to survive despite being in a consistent financial loss (Keller, 2009). Republika is very protective when it comes to its Islamic identity. When the paper went public in early 1993, it did not allow non-Muslims to purchase its shares, a move to prevent Muslim interests from being intervened by an outside force (Hill, 1994). Likewise, the same policy is also applied in the newsroom. Republika limits its non-Muslim membership that out of 117 Republika's employees there is only one person who is not a Muslim (Keller, 2009).

Republika implements five basic principles as its everyday ideological-daily basis; modern, moderate, Muslim, nationalist, and people-oriented. Its framework is "Amr bil Ma'ruf wa Nahy an al Munkar" (امر بالمعروف و نهى عن المنكر), a concept derived from the Quran which means enjoining right and forbidding wrong (Steele, 2018). Although Erick Thohir's acquisition in 2000 turned Republika into more commercial, its Islamic identity remains unaltered. In fact, Erick's market-oriented outlook seems to adapt well to Republika's commitment to serve Indonesian Muslims. It is Erick himself who wanted Republika to play more roles in improving the image of Islam. As he once said to Republika's staff that he did not want Islam to be seen as stupid, poor, and backward. Finally, Erick 
considers Muslims a niche market to whom all Republika employees have to always think about (Steele, 2018).

The tradition as an Islamic press with a strong commitment to protect Islam's interests in Republika and the influence of devout Catholic Jakob Oetama in Kompas, have inspired the two media to frame Ahok and his blasphemy case differently. Republika voiced strong condemnation against Ahok's speech to preserve the holiness of Islam. Such a robust ideological principle met its momentum when massive protests against Ahok took place across Indonesia. Because Muslims are Republika's targeted market, the media had no option except to write stories in accordance with the need of the market. Reporting Ahok's case is indeed challenging for Republika because the media is filled with Muslims with diverse Islamic viewpoints from secular to fundamentalist (Steele, 2018). The difference was apparent in Republika's Ahok and his case coverage. Nevertheless, Erick and Republika editorial board prioritized the Muslim market much more than its journalists' personal opinions. For in Republika the code of conduct for journalists is its traditional self-censorship ethic (Keller, 2009).

Moreover, Republika has a commitment to not trigger Muslim's anger on controversial issues such as the Ahok's case. Defending Ahok could have resulted in a protest by Islamic organizations, like the one by Lembaga Dakwah Islam Indonesia (Indonesian Institute for Islamic Predication) or LDII, back in December 30, 1996 (Hefner \& Horvatich, 1997). To prevent such an unwanted event from recurring, a gatekeeping procedure that excludes voices of liberal Muslims and other anti-mainstream sources has always been taken into practice. Republika denied getting involved in the debate of MUI's 2013 ruling on the Islamic organization's rejection of the banning of women circumcision, despite the issue being reported by other Indonesian media. Republika also strongly opposed LGBT and deemed it a serious threat. In 2016, Dompet Dhuafa, a Republika's non- 
profit organization, sponsored an anti-LGBT forum of experts, Islamic scholars, and ex-gays to send a message to the Islamic community that the paper still gripped Islamic teachings firmly (Steele, 2018).

As for Kompas, it is undeniable that Jakob has an almost unchallenged authority to govern the media (Wijayanto, 2019), allowing him to directly and indirectly dictate the framing of Ahok news. For Jakob, Ahok is a very important individual who matches with his life ideals and interests. Ahok's double minority as a Chinese and a Christian Protestant suits well with Jakob's transcendental humanism ideal which, as explained by Jong, is manifested in compassion. Compassion is interpreted as a sympathetic feeling and partisanship towards the weak (Kompas, 2016). In the Indonesian case, Ahok can be identified as 'weak' due to his racial and religious status, although in terms of socio-economic power Chinese Indonesians (BBC, 2018) and Christians (Kanas et al., 2015) are more superior than Muslims. For this reason, defending Ahok appears to be equal to defending the weak. Furthermore, to frame Ahok as a bad guy in such a context was quantitatively almost impossible for Kompas, even though Jakob was absent in the newsroom. Jakob has placed Catholics in Kompas's top positions for generations as a way to intentionally sustain the domination of Christian ideology and interests, making Muslim employees difficult to become chief editor (Wijayanto, 2019). Such domination, the heated tension of Jakarta election, and massive protests by Muslims across Indonesia earned Ahok enough support and solidarity from his catholic fellows in Kompas.

In defending Ahok, Jakob seemed not to mind going against some aspects of his life ideals. Jakob, for example, has a principle that Kompas needs to be critical and empathetic at the same time when covering a case (Wijayanto, 2019). He also internalizes his 'rasa' principle (a Javanese way of life) in Kompas which stresses on harmony and sympathy (Wijayanto, 2019). While these values were in use in Ahok's reporting, quantitatively, 
Kompas's amount of sympathy for Ahok was far greater than that of criticism. The strong sympathy is attributed to Kompas's tradition as a government's best partner or in the words of Ben Anderson, "New Order newspaper par excellence" (Hill, 1994). The partisan journalism etiquette remarkably intertwined with Jakob's ideological interests to protect Ahok just like what the media has done in issues involving Muslims and nonMuslims, which Kompas prefers to take the latter's side (Aprianti, 2014; Muslim, 2013; Sumartono, 2005).

In a larger context, both Kompas and Republika in reporting Ahok's case acted as platforms to accommodate the Clash of Civilizations (Huntington, 2011) in Indonesian political sphere between Christians and Muslims. Both groups fear each other, and they do not, to paraphrase Charles E. Farhadian's words, 'inhabit a shared world except when necessary' (Farhadian, 2009). In the context of the 2017 Jakarta Gubernatorial Election, it is difficult to deny the heated competition between the followers of these two Abrahamic religions. The Christian group had high hope in Ahok to begin a new era in Indonesian politics and put the hegemony of Muslims in strategic political positions to an end. Likewise, as the majority group, Muslims were not willing to be led by Christian-Chinese Ahok, for such a move would open the door for him or for any other non-Muslim politicians to become Indonesian president. These polarized groups were thirst for news to confirm their existing beliefs about Ahok and his blasphemy case which in turn set a competition between Kompas and Republika. As a consequence, both media flooded the internet with ideologically-motivated frames they created in order to inform readers about Ahok's case. The end goal of such a strategy was to promote manufactured frames to win readers' attention (Wu, 2018) and consent (Herman \& Chomsky, 2010). 


\section{Ahok in Kompas and Republika}

All the news articles containing the word Ahok within the timeframe were carefully analyzed using Akbarzadeh and Smith's coding guide (Akbarzadeh \& Smith, 2005: 9). The coding scheme allowed the researcher to classify the framing of each article to determine whether Ahok was framed in a positive, negative, neutral, or mixed way. This study classified articles as positive, negative, neutral, and mixed based on the framing and the language of each news story. The adjectives used to describe Ahok, the story selection, and the inclusion or exclusion of certain voices in commenting or supporting Ahok affected the tone of a story.

Table 1.

Numbers of Positive, Negative, Neutral, and Mixed articles from Kompas and Republika Online

\begin{tabular}{lccccc}
\hline Media & Positive & Negative & Neutral & Mixed & Numbers of articles \\
Kompas & 273 & 27 & 158 & 30 & 488 \\
Republika & 65 & 192 & 572 & 179 & 1008 \\
& & & & & \\
\hline
\end{tabular}

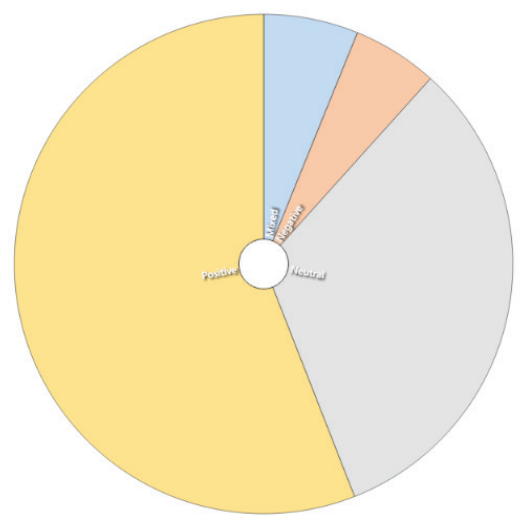

Figure 1. Positive, Negative, Neutral, and Mixed articles from Kompas Online

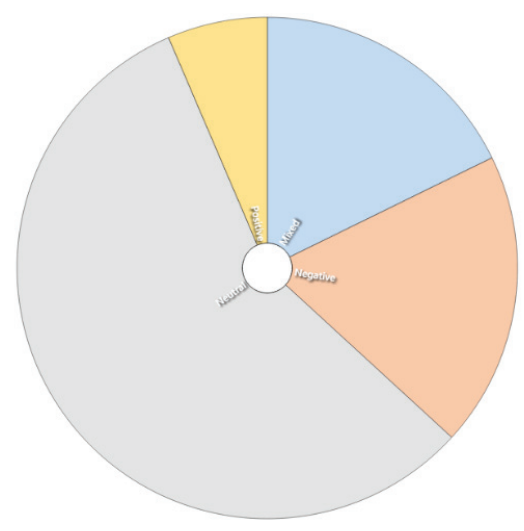

Figure 2. Positive, Negative, Neutral, and Mixed articles from Republika Online 
It is clear from the table that Republika covered more news than Kompas, with an excess of more than $50 \%$ coverage. In terms of positive, negative, neutral, and mixed reports the table and the pie charts demonstrate a contrasting different style. Kompas was more determined to frame Ahok positively and at the same time committed to offering a neutral stance. Republika, on the other hand, attempted to provide neutral news as its main framing of Ahok. Negative framing appears to be not a commitment for Republika.

The majority of positive articles analyzed in this research demonstrate a strong editorial policy of Kompas to frame Ahok as an outstanding leader. Ahok was portrayed as an exceptional, heroic figure who dared to fight irregularities against all kinds of peoples and institutions: ordinary people, senators, court officials, politicians, and government offices. This also included the acting governor Sumarsono who replaced then incumbent Ahok when he was taking a break for his re-election campaign. Kompas even took Ahok's side in controversial policies such as forced evictions, the Jakarta bay reclamation project, and Ahok's blasphemy case. In the case of forced evictions for instance, Kompas rarely used the word 'eviction'. Instead it preferred 'relocation of unpermitted residents' to soften the reporting tone of the event. The moral evaluation of the eviction framing is to normalize rivers to overcome Jakarta flooding.

Meanwhile, Republika's positive framing of Ahok is mainly related to his office activities, programs, and his reelection candidacy. Republika rarely gave positive framing based on his personality like what Kompas always did. The exception is only in September before the controversial blasphemy case occurred. In that period, Republika seemed to join the echo chamber of Indonesian media to cash in on everything about Ahok. Ahok, together with Jokowi, grabbed the attention of Indonesian mainstream media in 2012 when both young politicians ran for Jakarta governor office. Some oligarchs were involved behind the making of the 
two politicians as Indonesian media darling (Tapsell, 2015a). But even so, Republika still gave room for critical news about Ahok. In the case of the Bukit Duri's incident for instance, Republika firmly exercised its duty as a watchdog by framing Ahok's eviction negatively, reporting the eviction story using residents' and human rights activists' perspectives.

Ahok was hardly framed negatively by Kompas. When the online media did report negative news about him, its number was not significant, and the framing was generally non-inflammatory. Exceptions were only news articles citing Hashim's (brother of Prabowo) opinion about Ahok and LBH Jakarta's voice on Ahok's eviction in which Ahok was framed highly negatively. Other exceptions were when Kompas framed Ahok as a bad Christian whom did not deserve to get support for the ensuing election and his 2016 forced eviction policy which was classified as human rights abuses. However, despite all the critical reporting, it is noticeable that Kompas did not apply overly negative framing.

Republika's negative news about Ahok aimed to counter frame Kompas's reporting. In response to Kompas's framing of Ahok's sincere love for Islam, Republika asserted the man was not eligible to be included into the 'we' camp of Islam. Republika believed that Ahok's confessions stating his strong connection to Islam were just a fabrication intended to win the support of the mass and to build a popular opinion that himself was not anti-Islam. Republika also refuted Ahok's self-identification of being an Indonesia's Nelson Mandela, an acknowledgment made by Ahok on the ground of the same imprisonment terms both himself and Mandela served. To rebut this, Republika opted to feature voices that passionately opposed Ahok's claim saying that Mandela's historical background, his attitude, and his political activism were contrastingly different to Ahok's. For them, Ahok remained to be a serious problem for Indonesian society. These negative comments were selected by Republika to support its 'bad Ahok' framing whose nature was not at the same level as Nelson Mandela. 
Both Kompas and Republika covered many stories about Ahok with neutral framing featuring Ahok's activities as a governor and an individual, his trial and blasphemy case development, his debates prior to the Jakarta election, issues on Jakarta election, and Jakarta government affairs. All these themes did not use inflammatory frames to support or condemn Ahok, but rather reporting facts as they were. There was no significant framing difference betweem both media in their reporting of neutral news about Ahok. In an article on Ahok's exception trial for instance, Kompas neither discussed Ahok's positive personality, nor framed him as a damaging individual. The article did include positive framing in the end to explain Ahok's exception which may suggest a positive attitude of Kompas towards Ahok. But it was just a reporting of facts using fair frames without inserting supported or opposed adjectives to the facts. For Republika where neutral news was the most dominant theme, framed issues were varied focusing on Ahok's gubernatorial and post gubernatorial activities, trial development, his candidacy, and plans after losing the election. The central framing point was similar to that of positive news, and the only difference was in terms of quantity as seen in the table and the pie charts.

Mixed articles featured negative framing about Ahok, but at the same time positive framing was also included. In terms of news focus, there was no significant difference between Kompas and Republika, which used gubernatorial and post gubernatorial activities, trial development, plans after losing the election and Ahok's candidacy as a basis of coverage. Kompas and Republika cited both parties involved in a story of their mixed news as an effort to practice a balanced reporting.

\section{Ahok's Blasphemy Case in Kompas and Republika}

There were four framing themes identified in the 275 articles produced by Kompas and Republika: defending Ahok, accusing Ahok to 
Al-Balagh: Jurnal Dakwah dan Komunikasi,

Vol. 5, No. 1, January - June 2020, pp. 59 - 94, DOI: https://doi.org/10.22515/al-balagh.v5i1.1991 ISSN: 2527-5704 (P) ISSN: 2527-5682 (E)

have blasphemed Islam, calls for Ahok imprisonment, and Al-Maidah 51 is politically used against Ahok.

Table 2.

Numbers of articles on Ahok's Blasphemy Case in Kompas and Republika

\begin{tabular}{lcc}
\hline Period & Kompas & Republika \\
\hline 27 - 30 September 2016 & 1 & 0 \\
October 2016 & 14 & 73 \\
November 2016 & 28 & 74 \\
December 2016 & 6 & 16 \\
January 2017 & 3 & 5 \\
February 2017 & 2 & 17 \\
March 2017 & 3 & 16 \\
April 2017 & 6 & 5 \\
1-15 May 2017 & 2 & 4 \\
Total & $\mathbf{6 5}$ & $\mathbf{2 1 0}$ \\
\hline
\end{tabular}

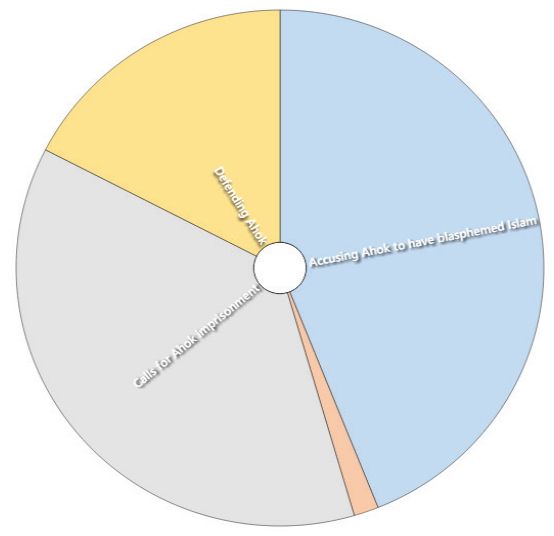

Figure 3. Republika Frames

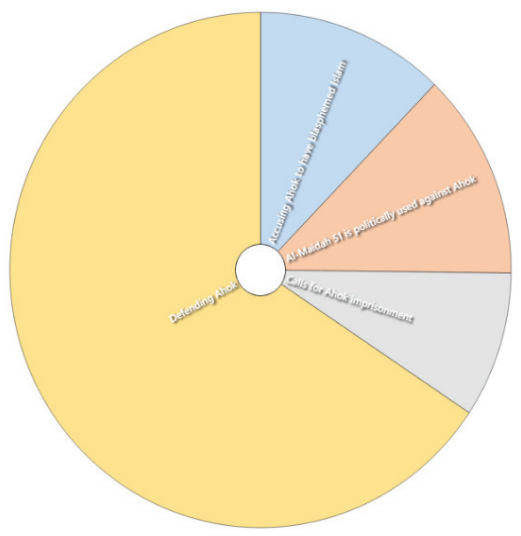

Figure 4. Kompas Frames 


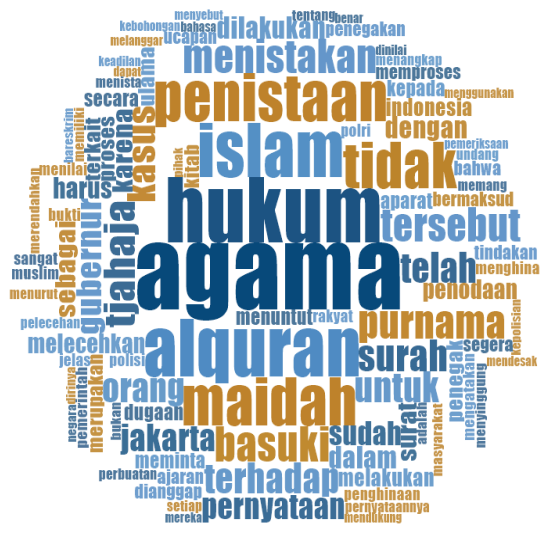

Figure 5. Kompas word frequency

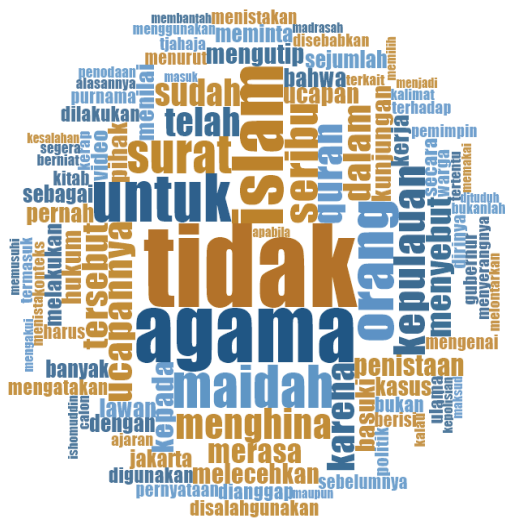

Figure 6. Republika word frequency

From the table it is clear that Republika reported far more news on Ahok's blasphemy case than Kompas. In terms of the four themes, Kompas dominated its framing with defending Ahok. Its accusation of Ahok's case being politically motivated was just slightly higher than those of accusing Ahok to have blasphemed Islam and calls for his imprisonment. Republika, on the other hand, strongly accused Ahok to have blasphemed Islam, and urged the government to put him behind bars. Interestingly, Republika had a quite large portion of reporting that defended Ahok. Meanwhile, Kompas's accusation of the political motives behind Ahok's case had very little interest for Republika. Finally, the frequent words used by Kompas in the analyzed news samples were 'no', 'religion' and 'maidah' suggesting that Ahok did not defame Al Maidah and Islam. Republika's three most frequent words were 'religion', 'law', 'Al-Qur'an', signifying that Ahok had blasphemed Islam and Al-Qur'an, and as a consequence he had to be punished. It may be confusing why the same words in Republika and Kompas such as 'religion', 'Al-Qur'an' and Al-Maidah were interpreted differently. They mean dissimilar due to the association made by each media in describing them. 'Religion' in Kompas was associated with the fact that Ahok did not blaspheme Islam, whereas 
in Republika the connection of the word was with Ahok's intention to blaspheme Islam.

As seen in the pie chart, Kompas dominated its reporting with news that aimed to defend Ahok, and the message wished to deliver to its readers was that Ahok was not guilty and thus he had to be defended. Kompas repeatedly stated in its coverage that Ahok just cited a verse from the Al-Qur'an in his visit to Kepulauan Seribu, to influence readers' opinion on Ahok's blasphemy case. In defending Ahok, Kompas cited Ahok's statements regarding his case in most of its coverage. Moreover, Kompas framed Ahok as a victim of his political opponents whose goal was to kill his reputation and ended his chance to win the upcoming election.

To strengthen its guiltless Ahok framing, Kompas covered stories using 'Islamic' perspectives to create a sense of confusion among readers. Kompas cited a Gusdur's opinion on the contextual meaning of AlMaidah 51 that he once interpreted the verse to be not applicable to the election of a government leader. A senior member of the Indonesian Ulema Council (Majelis Ulama Indonesia/MUI), Hamka Haq, was also featured by Kompas to strengthen the framing. Hamka Haq argued that Ahok neither blasphemed Islam nor insulted Indonesian Ulemas because his visit to Kepulauan Seribu was not to spread a new religion to Muslims. Another voice used by Kompas for the defensive framing was from Nahdlatul Ulama (PBNU). PBNU in fact became a dominant internal source of information cited by Kompas in its defense of Ahok. Articles discussing the statements of PBNU to stop the politicization of religion as well as to give the same rights to Muslims and non-Muslims to lead Jakarta were associated with Ahok and his case. The moral evaluation of these articles was that, while Kompas was trying to defend Ahok, it also implicitly deconstructed the framing possessed by many Muslims in Indonesia regarding their belief that non-Muslims were not allowed to vote for. Such framing was intended to garner Muslim votes to help Ahok win the election. 
Despite its opposition, Republika demonstrated willingness to defend Ahok by covering some news with defensive framing. The scheme, however, was not as pure and highly dedicated as Kompas due to the fact that Republika tended to associate the defensive framing with an accusation and a depiction that Ahok had blasphemed Islam. Republika also included voices of Islamic scholars from NU and Muhammadiyah who defended Ahok. The voices, although a minority, were evidence that Republika still gave room for Muslims who had different notions from the media company's and the Indonesian Muslims' at large. Even so, Republika remained firm to keep its stance on Ahok's case by limiting the supportive voices as well as harming them through attacks launched in other articles. The 'Islamic Ahok' as framed by Kompas was countered by Republika with another framing accusing Ahok to have intentionally blasphemed Islam. Republika employed the same framing strategy to counter the widely circulated framing that positioned Ahok being a victim of SARA (ethnicity, religion, race, and other social divisions). For Republika Ahok was a perpetrator of SARA, rather than a victim as evidenced in his controversial speech.

Ahok's speech was strongly condemned by Republika and was framed as a blasphemy. Republika also framed Ahok's case as an extraordinary legal offense that had a tendency to spread hatred and threatened the unity of Indonesia. It is Republika's conviction that Ahok had had prejudice against Islam which in turn inspired him to deliver the controversial speech. To support the framing, Republika cited a number of people, mostly prominent Muslim figures, who shared the same stance on the case. All these people, except a few ones such as those in the defending Ahok's section, condemned Ahok and accused him to have blasphemed the religion of Islam. Republika also included statements of a PBNU top official who accused Ahok's speech to cause confusion for Muslims. Likewise, in framing the evolving blasphemy issue, Republika stated that Ahok and Blasphemy Case in Kompas and Republika Online Media: A Clash of Ideologies 
Ahok's Al Maidah statement had the potential to drag Muslims to a wrong destination.

Republika's firm accusation that Ahok had blasphemed Islam was also demonstrated by Kompas. The difference was only on framing quantity of which Republika being far more massive than Kompas. Kompas displayed a strong condemnation against Ahok's controversial speech in much of its coverage, but at the same time a moral evaluation considering him to have made a mistake was also imbued. To illustrate, Kompas covered Ahok's trial in a persecutor's perspective who accused Ahok's plea to have the potential to break the unity of Indonesia. The same negative framing was also employed against Ahok's book which contains a sub-chapter entitled 'hiding behind sacred verses'. The subchapter was dedicated to Muslims who used Al-Maidah 51 for political interests, the very same thinking as that in Ahok's controversial speech. Despite this accusation, Kompas inserted defensive framing in favour of Ahok in most of its critical news, although not dominating the narrative of the news. It has been Kompas's commitment, as the previous analysis has demonstrated, to frame Ahok's visit to Kepulauan Seribu as his honest confession, that the island residents did not need to vote for him. The clarification suggested Kompas's eagerness to promote a frame that Ahok's visit had nothing to do with the blasphemy of a religion. Another strategy that Kompas utilized in its framing of the Ahok's case was by attempting to harm the legitimacy of the MUI, the body that issued a ruling (fatwa) accusing Ahok to blaspheme Islam. In its coverage Kompas used an MUI's perspective while at the same time softly framed its action as negligence.

Another moral evaluation disseminated by Kompas was on AlMaidah 51 being used to stop Ahok's re-election. Kompas associated its coverage on Ahok's trial with a strong frame arguing that Al-Maidah 51 was used by some irresponsible people and that Ahok's political opponents 
used the verse to attack him. Nevertheless, Kompas also attempted to make balanced news to exercise its duty to report facts 'objectively' or as they were. In Ahok's case Kompas had no power to contest facts that some organizations and Muslims had reported Ahok to the police and that Ahok had been put on trial for the case. But Kompas had the capability and independence to make the news appear 'balanced' by inserting Ahok's voice under the principle of covering both sides. In doing so, Kompas had a total authority to select relevant information to feature and what framing was best to supplement it.

The framing that Al-Maidah 51 was used against Ahok had least interest in Republika, suggesting the Islamic media's strong commitment not to take Ahok's side. The only framing in this category was from NU officials who argued that there had been some people who used the verse for political interests. Yet, Republika did not apply firm framing to the issue to preserve its commitment that Ahok had blasphemed Islam.

Ahok's controversial speech garnered condemnation from many segments of Muslim societies prompting Republika to transmit Muslim's concerns. As an Islamic media, Republika covered stories from the Muslim side with Muslim organizations' voices on mass protests against Ahok being the most dominant. In covering the protests, Republika focused on protestors' messages that urged the government to imprison Ahok. Security framing was also amplified that Indonesia would likely turn into a chaotic state if Ahok was not detained. A number of articles clearly demonstrated Republika's framing of Ahok as a potential source of turmoil. Such framing was intended to put pressure on the police amid the mass protests occurring in many regions of Indonesia. Furthermore, for Republika Ahok had done a serious crime and had to be punished as soon as possible. Republika urged the police to be professional because a circulating allegation informed that the police may have been protecting Ahok. What is more, Republika warned the general public to always be Ahok and Blasphemy Case in Kompas and Republika Online Media: A Clash of Ideologies 
alert on the development of Ahok's case so that it would not turn out, like the Sumber Waras case whose probing process had been halted despite irregularities found in it. Not only that, for Republika Ahok was backed by a superpower force that had the capability to get him protected by the state. To strengthen its framing, Republika cited some prominent Indonesian figures whose voices were the same as Republika's. A house representative from East Nusa Tenggara Province, for example, argued that Ahok's case had the potential to turn Indonesia into a catastrophic conflict like the 1998 anti-Suharto riot. This framing aimed to legitimate the urgency to detain Ahok as a house member can be interpreted as an official representation of the Indonesian people. Republika also cited former president Susilo Bambang Yudhoyono to amplify the urgency of Ahok's detainment framing.

Kompas framed the calls for Ahok's imprisonment with mixed messages. On the one side, it covered stories that entirely framed Ahok as a person who had to be detained by the police. But on the other hand, such stories were featured with a reminder of Ahok's guiltless act in relation to his blasphemy case. In some of its news Kompas openly attempted to give an understanding to readers that the mass was protesting against Ahok whom in fact had not done any wrongdoings. For this reason, Kompas believed that the protests were misguided and those taking part in them were uninformed of what really had happened. Kompas also employed diversion strategy to switch readers' attention by softly persuading them to associate Ahok's case with SARA. The moral evaluation was that Ahok was not guilty as he was just a victim of SARA launched by his political opponents. 


\section{CONCLUSION AND SUGGESTION}

\section{Conclusion}

This paper has demonstrated the different patterns of framing in Kompas and Republika on Ahok and his Al-Maidah blasphemy case. Massive amount of news was released by both media to amplify their manufactured-frames to win public support on Ahok, and in particular on the blasphemy case he was facing. In the periods of eight months (232 days) of the research timeframe, on average Kompas published 2 news articles a day, while Republika reported 4 articles. As shown in the previous chapter, Kompas dominated its stories about Ahok with positive reporting to display solidarity for the Christian governor in an indirect way. Kompas also attempted to balance its reporting as evident in the big proportion of its neutral news. Republika on the other hand, despite taking an opposite position regarding Ahok's case, dominated its reporting with neutral news. Yet, negative news was also clearly seen and had a quite large proportion in the reporting focus of the Islamic media. Republika's negative news was aimed at countering Kompas's framing to polish Ahok as a great man.

As for Ahok's blasphemy case, Kompas demonstrated its strong willingness to defend Ahok. Among 210 news articles on the topic, the dominant frame was defending Ahok, followed by an argument that AlMaidah 51 was used for politically-motivated purposes to harm Ahok's political career. Yet, interestingly, the proportion of this political motive framing was just slightly higher than that of accusing Ahok to have blasphemed Islam. It seems Kompas fully realized that the case being faced by Ahok was difficult to challenge due to a strong condemnation by Muslims across Indonesia. It was becoming more impossible to excessively challenge the court ruling regarding Ahok's legal status. Insistence would harm Kompas's reputation as a trusted source of information. Therefore, 
the only possible ways to frame Ahok's blasphemy case were through defensive framing and at the same time, although less intensive and infrequently, launching a framing attack on Ahok.

The different framing strategies of Kompas and Republika in reporting Ahok and his case may have impacted may have impacted on readers over their understanding of what was really going on. Readers may have formed a sympathetic or opposed feeling about Ahok due to the news stories they read from Kompas and Republika. When Ahok was associated with good news, a good image of him may have been created in the minds of readers, and therefore they may have been willing to give support to Ahok. On the other hand, when Ahok was reported with negative stories, readers would tend to believe that Ahok was not that a good guy because focuses and stresses in the reporting were placed on negative facts. Nonetheless, the apparent framing differences between Kompas and Republika on Ahok and his case mirrored a clash of ideologies between the two media.

\section{Suggestion}

For future research, with the advent of information technologies that influence the making and flow of news frames, it is essential to study the roles played by Entman's five framing components: the platform (social media like Google, Facebook, Twitter), analytics (data about audience behavior), algorithms, and ideological media (Robert M. Entman \& Usher, 2018) in amplifying and even triggering a clash of ideologies between Indonesian media. Such an analysis becomes more imperative for Indonesia owing to the fact that a large number of social media users, political influencers as well as buzzers have have been actively muddying Indonesian politics. 


\section{REFERENCES}

Aelst, P., Strömbäck, J., Aalberg, T., Esser, F., Vreese, C., Matthes, J., Hopmann, D., Salgado, S., Hubé, N., Stępińska, A., Papathanassopoulos, S., Berganza, R., Legnante, G., Reinemann, C., Sheafer, T., \& Stanyer, J. (2017). Political Communication in A High-choice Media Environment: A Challenge for Democracy? Annals of the International Communication Association, 41(1), 3-27. https://doi.org/10.1080/23808985.2017.1288551

Alexa. (2019). Top Sites in Indonesia. Retrieved February 3, 2019, from alexa. com website: https://www.alexa.com/topsites/countries/ID

Alonso, M. O. (2014). The Triangle Formed by Framing, Agenda-setting and Metacoverage. Disertaciones: Anuario Electrónico de Estudios En Comunicación Social, 7(1), 41-66. https://doi.org/10.12804/ disertaciones.v7i1.4423

Althusser, L. (2006). Ideology and Ideological State Apparatuses (Notes towards an Investigation). In A. Sharma \& A. Gupta (Eds.), The Anthropology of the State: A Reader (Vol. 9, Issue 1, pp. 86-98). Hoboken, New Jersey, United States: Blackwell Publishing.

Anggraeni, D. (2018). Analisis Framing Entman Berita Tata Kelola Pangan di Media Online. Jurnal The Messenger, 10(1), 113-114. https://doi. org/http:/10.26623/themessenger.v10i1.711

Aprianti, R. (2014). Melihat Objektifitas Media Massa Terhadap Pernyataan Paus Benedictus XVI. Jurnal Dakwah, 15(2), 357-381. https://doi. org/10.14421/jd.2014.15207

Azpíroz, M. L. (2014). Framing and Political Discourse Analysis: Bush's Trip to Europe in 2005. Observatorio, 8(3), 75-96. https://doi. org $/ 10.7458 /$ obs 832014763

BBC. (2018). Orang terkaya Indonesia 2018: Siapa saja dan dari mana sumbernya? Retrieved February 3, 2019, from bbc.com website: https://www. bbc.com/indonesia/trensosial-46549111

Borah, P. (2011). Conceptual Issues in Framing Theory: A Systematic Examination of a Decade's Literature. Journal of Communication, 61, 246-263. https://doi.org/10.1111/j.1460-2466.2011.01539.x

Brugman, B. C., \& Burgers, C. (2018). Political Framing Across Disciplines: Evidence from 21st-Century Experiments. Research and Politics, 
Al-Balagh: Jurnal Dakwah dan Komunikasi,

Vol. 5, No. 1, January - June 2020, pp. 59 - 94, DOI: https://doi.org/10.22515/al-balagh.v5i1.1991

ISSN: 2527-5704 (P) ISSN: 2527-5682 (E)

$$
\text { 5(2), 1-7. https://doi.org/10.1177/205316801878337 }
$$

Castells, M. (2013). Communication Power. Oxford, UK: Oxford University Press.

Chong, D., Druckman., \& James, N. (2007). Framing Theory. Annual Review of Political Science, 10, 103-126. https://doi.org/doi: 10.1146/ annurev.polisci.10.072805.103054

Croteau, D., \& Hoynes, W. (2013). Media/Society: Industries, Images, and Audiences (5th ed.). Thousand Oaks, California, United States: SAGE Publications.

Edhlund, B., \& McDougall, A. (2019). NVivo 12 Essentials. Morrisville, North Carolina, United States: Lulu.com.

Entman, R. M. (1993). Framing: Toward Clarification of a Fractured Paradigm. Journal of Communication, 43(4), 51-58. https://doi. org/10.1111/j.1460-2466.1993.tb01304.x.

Entman, R. M. (2004). Projections of Power: Framing News, Public Opinion, and US Foreign Policy. Chicago, Illinois, United States: University of Chicago Press.

Entman, R. M. (2007). Framing Bias: Media in the Distribution of Power. Journal of Communication, 57(1), 163-173. https://doi.org/10.1111/ j.1460-2466.2006.00336.x

Entman, Robert M., \& Usher, N. (2018). Framing in a Fractured Democracy: Impacts of Digital Technology on Ideology, Power and Cascading Network Activation. Journal of Communication, 68(2), 298 308. https://doi.org/10.1093/joc/jqx019.

Farhadian, C. E. (2009). Christianity, Islam and nationalism in Indonesia. Abingdon, United Kingdom: Routledge.

Ferry, L. (2002). Man Made God: The Meaning of Life. Chicago, Illinois, United States: University of Chicago Press.

Galih, B. (2016). Pernyataan Pastor Oudejans yang Mengubah Pandangan Seorang Jakob Oetama. Retrieved February 3, 2019, from www.youtube.com website: https://www.tribunnews.com/nasional/2016/09/27/ pernyataan-pastor-oudejans-yang-mengubah-pandangan-seorangjakob-oetama

Gitlin, T. (2003). The Whole World is Watching: Mass Media in the Making and Unmaking of the New Left. Berkeley, California, United States: University of California Press. 
Goldin, J., \& Reck, D. (2019). Revealed Preference Analysis with Framing Effects. Journal of Political Econom, 128(7). https://doi. org/10.1086/706860

Gronemeyer, M. E., \& Porath, W. (2017). Framing Political News in the Chilean Press: The persistence of the Conflict Frame. International Journal of Communication, 11, 2940-2963.

Hänggli, R., \& Kriesi, H. (2010). Political Framing Strategies and Their Impact on Media Framing in a Swiss Direct-Democratic Campaign. Political Communication, 27(2), 141-157. https://doi. org $/ 10.1080 / 10584600903501484$

Hefner, R. W. (1997). Print Islam: Mass Media and Ideological Rivalries among Indonesian Muslims. Language and Media, 64, 77-103. https://doi.org/10.2307/3351436.

Hefner, R. W., \& Horvatich, P. (Eds.). (1997). Islam in an Era of NationStates: Politics and Religious Renewal in Muslim Southeast Asia. Honolulu, Hawai: University of Hawaii Press.

Hefner, Robert W. (1993). Islam, State, and Civil Society: ICMI and the Struggle for the Indonesian Middle Class. Indonesia, 56, 1-35. https://doi.org/10.2307/3351197

Herman, E. S., \& Chomsky, N. (2010). Manufacturing Consent: the Political Economy of the Mass Media. New York, New York, United States: Random House.

Hill, D. T. (1994). The Press in New Order Indonesia. Sheffield, United Kingdom, London, United Kingdom: Equinox Publ.

Hoon, C.-Y. (2016). Religious Aspirations among Urban Christians in Contemporary Indonesia. International Sociology, 31(4), 413-431. https://doi.org/10.1177/0268580916643853.

Huntington, S. (2011). The Clash of Civilizations and The Remaking of World Order. New York, New York, United States: Simon \&S chuster.

Jackson, K., \& Bazeley, P. (2019). Qualitative Data Analysis with Nvivo. Thousand Oaks, California, United States: SAGE Publications Limited

Ilham. (2017). Mengungkap Alasan Ahok-Djarot Menang Mutlak di Dua TPS. Republika Online. Retrieved February 3, 2019, from republika.co.id website: http://republika.co.id/berita/nasional/ politik/17/02/17/olhwm3361-mengungkap-alasan-ahokdjarot- 
menang-mutlak-di-dua-tps

Indra K, Briliant, \& Suprihartini, T. (2017). Analisis Framing dalam Kasus Kontroversi Ahok di dalam Pilkada DKI Jakarta 2017-2022 di dalam Media Online Kompas.com dan Republika.co.id. Interaksi Online, 5(3), 1-13. https://ejournal3.undip.ac.id/index.php/ interaksi-online/article/view/16875

Kanas, A., Scheepers, P., \& Sterkens, C. (2015). Interreligious Contact, Perceived Group Threat, and Perceived Discrimination: Predicting Negative Attitudes Among Religious Minorities And Majorities in Indonesia. Social Psychology Quarterly, 78(2), 102-126. https://doi. org/10.1177/0190272514564790.

Keller, A. (2009). Tantangan dari Dalam: Otonomi Redaksi di 4 Media Cetake Nasional: Kompas, Koran Tempo, Media Indonesia, Republika [Challenge from inside: Editorial Autonomy at 4 National Print Media: Kompas, Koran Tempo, Media Indonesia, Republika]. Jakarta: FES Indonesia Office.

Khadafi, A. (2017). Faktor Agama Menentukan Kemenangan Anies-Sandiaga. Retrieved February 3, 2019, from www.tirto.id website: https:// tirto.id/faktor-agama-menentukan-kemenangan-anies-sandiagacm79

Kompas. (2016). VIK - The Legacy 85 Tahun Jakob Oetama. Retrieved February 3, 2019, from vik.kompas.com website: https://vik. kompas.com/the-legacy-jakob-oetama/

Lim, M. (2017). Freedom to hate: social media, algorithmic enclaves, and the rise of tribal nationalism in Indonesia. Critical Asian Studies, 49(3), 411-427. https://doi.org/https://doi.org/10.1080/14672 715.2017 .1341188

Lim, M., \& Arizona, A. (2011). Democratization \& Corporatization of Media in Indonesia. Arizona: Arizona State University.

Marx, K., \& Engels, F. (1972). The German Ideology (Vol. 1). New York, New York, United States: International Publishers Co.

Matthes, J. (2012). Framing Politics: an Integrative Approach. American Behavioral Scientist, 56(3), 247 -259. https://doi. org $/ 10.1177 / 0002764211426324$

Mayasari, S. (2017). Konstruksi Media Terhadap Berita Kasus Penistaan Agama Oleh Basuki Tjahaja Purnama (Ahok): Analisis Framing Pada Surat Kabar Kompas dan Republik. Jurnal Komunikasi, 8(2), 
8-18. https://doi.org/10.31294/jkom.v8i2.2528

McQuail, D. (2010). McQuail's Mass Communication Theory. Thousand Oaks, California, United States: SAGE Publications.

Media, M. (2019). Mahaka Media - Business Unit. Retrieved February 3, 2019, from mahamedia.com website: https://mahakamedia.com/ tentang_kami/unit_bisnis

Mujiburrahman. (2006). Feeling Threatened: Muslim-Christian Relations in Indonesia's New Order. Nieuwe Prinsengracht, Amsterdam, Netherlands, Amsterdam, Netherlands: Amsterdam University Press.

Muslim, M. (2013). Konstruksi Media Tentang Serangan Israel Terhadap Libanon (Analisis Framing Terhadap Berita Tentang Peperangan Antara Israel Dan Libanon Dalam Surat Kabar Kompas Dan Republika). Jurnal Studi Komunikasi Dan Media, 17(1), 75-92. https://doi.org/10.17933/jskm.2013.170104

Nautico, T. (2018). Construction of the Republika Portal Against the Ahok Blasphemy Case Verdict. 2nd ICSSED 2018, 131.

Nurhaliza, H., \& Tanto, T. (2019). Representation of Indonesia's Judiciary of Ahok's Blasphemy Verdict in The New York Times Analysis (A Critical Discourse).K@Ta: A Binnual Publication On The Study Of Language And Literature, 21(2), 68-74.

Pan, Z., \& Kosicki, G. M. (1993). Framing analysis: An approach to News Discourse. Political Communication, 10(1), 55-75. https://doi.org/1 0.1080/10584609.1993.9962963

Purwadi, D. (2017). Belajar dari Etnis Cina dan Non-Muslim dalam Pilkada DKI. Retrieved February 3, 2019, from republika.co.id website: http:// republika.co.id/berita/jurnalisme-warga/wacana/17/02/18/ olkd8i257-belajar-dari-etnis-cina-dan-nonmuslim-dalam-pilkadadki

Raharjo, B. (2017). Pengalaman Republika, Ini TantanganMengelolaMedia Muslim. Retrieved February 3, 2019, from republika.co.id website: http:// nasional.republika.co.id/berita/nasional/umum/17/11/18/ ozly8f415-pengalaman-republika-ini-tantangan-mengelola-mediamuslim

Reily, M. (2017). Nielsen: Pembaca Media Digital Sudah Lampani Media Cetak. 
Retrieved February 3, 2019, from katadata.co.id website: https:// katadata.co.id/berita/2017/12/07/nielsen-pembaca-mediadigital-sudah-lampaui-media-cetak

Riana, F. (2016). Survei LSI: Ahok Bisa Kalah Karena Isu Agama. Retrieved February 3, 2019, from tempo.co website: https://nasional.tempo. $\mathrm{co} / \mathrm{read} / 810478 /$ survei-lsi-ahok-bisa-kalah-karena-isu-agama/ full\&view $=$ ok.

RMOL. (2017). Ketum Pemuda Muhammadiyah Puji Soliditas Kaum Kristiani Dan Etnis Cina Dukung Ahok. Retrieved February 3, 2019, from rmol. com website: http://politik.rmol.co/read/2017/02/17/280785/ Ketum-Pemuda-Muhammadiyah-Puji-Soliditas-Kaum-KristianiDan-Etnis-Cina-Dukung-Ahok-

Scheufele, B. (2004). Framing-effects Approach: A Theoretical and Methodological Critique. Communications, 29(4), 401-428. https:// doi.org/10.1515/comm.2004.29.4.401.

Scheufele, D. A. (1999). Framing as a Theory of Media Effects. Journal of Communication, 49(1), 103-122. https://doi. org/10.1111/j.1460-2466.1999.tb02784.x

Scheufele, D. A., \& Tewksbury, D. (2007). Framing, Agenda Setting, and Priming: The Evolution of Three Media Effects Models. Journal of Communication, 57(1), 9-20. https://doi.org/10.1111/j.14602466.2006.00326.x.

Sidik, F. (2017). Objectivity of republika. co. id in Reporting the Trial Court of Religion Blasphemy with Ahok as Defendant. Borderless Communities \& Nations with Borders, 959.

Sobari, T., \& Ramdani, D. (2019). Framing Religious Blasphemy Issues By the Governor of DKI Basuki Tjahaja Purnama in the Contestation of Governor Election DKI. In International Conference on Interdisciplinary Language, Literature and Education (ICILLE 2018), April. https://doi.org/10.2991/icille-18.2019.88

Steele, J. E. (2018). Mediating Islam: cosmopolitan journalisms in Muslim Southeast Asia. Seattle, Washington, United States: University of Washington Press

Suganda, D., Sunarni, N., \& Darmayanti, N. (2018). News of Islamic Blasphemy onthe Websites of Kompas and Republika: A Critical Discourse Analysis. ISLLE 2017, The 1st International Seminar on 
Language, Literature and Education, KnE Social Sciences, 1(302-317). https://doi.org/10.18502/kss.v3i9.2692

Sumartono, S. (2005). Objektivitas Konflik Ambon Pada Pemberitaan Kompas dan Republika. Jurnal Komunikologi (Ilmu Komunikasi), 2(2).

Tamburaka, A. (2013). Literasi Media: Cerdas Bermedia Khalayak Media Massa. Depok: Rajagrafindo Persada.

Tapsell, R. (2012a). Old Tricks in a New Era: Self-Censorship in Indonesian Journalism. Asian Studies Review, 36(2), 227-245. https://doi.org/1 0.1080/10357823.2012.685926

Tapsell, R. (2012b). Politics and the Press in Indonesia. Media Asia, 39(2), 109-116. https://doi.org/01296612.2012.11689925

Tapsell, R. (2015). Platform Convergence in Indonesia: Challenges and Opportunities for Media Freedom. Convergence, 21(2), 182-197. https://doi.org/10.1177/1354856514531527

Wahid, S. W., \& Pratiwi, R. Z. B. (2018). The Construction of Tionghoa Ethnic Stereotype in Ngenest Movie. Jurnal Ilmu Komunikasi, 1(2), 54-66. https://doi.org/10.33005/jkom.v0i2.24

Wibiyanto, A., \& Hastiningsih, W. T. (2019). Pengelolaan Isu Pemilihan Umum Presiden Republik Indonesia Tahun 2019 pada Media di Jawa Tengah. Al-Balagh: Jurnal Dakwah Dan Komunikasi, 4(2), 263 292. https://doi.org/10.22515/balagh.v4i2.1832

Wijayanto. (2017). Fearing the Majority: Catholic Media in Muslim Indonesia. Media Asia, 44(1), 33-39. https://doi.org/10.1080/01 296612.2017.1374319

Wijayanto, W. (2019). Between fear and power: Kompas, Indonesia's most influential daily newspaper, 1965-2010 [PhD Thesis].

Winters, J. A. (2013). Oligarchy and Democracy in Indonesia. Indonesia, 96(1), 11-33. https://doi.org/10.5728/indonesia.96.0099

Wolton, S. (2019). Are Biased Media Bad for Democracy? American Journal of Political Science, 63(3), 548-562. https://doi.org/10.1111/ ajps.12424

Wu, T. (2018). Is the First Amendment Obsolete. Mich. L. Rev., 117, 547.

Yani, B. (2002). Reporting the Maluku Sectarian Conflict: The Politics of Editorship in Kompas and Republika Dailies. Saarbrücken, Germany: VDM Verlag 
Al-Balagh: Jurnal Dakwah dan Komunikasi,

Vol. 5, No. 1, January - June 2020, pp. 59 - 94, DOI: https://doi.org/10.22515/al-balagh.v5i1.1991 ISSN: 2527-5704 (P) ISSN: 2527-5682 (E) 